\title{
ANALYSIS OF LAND USE/LAND COVER CHANGE AND ITS PREDICTION IN THE MAMBASA SECTOR, DEMOCRATIC REPUBLIC OF CONGO
}

\author{
OPELELE, O. M. ${ }^{1,2,3}-$ FAN, W. Y. ${ }^{1,2^{*}}-$ YU, Y. ${ }^{1,2}-$ KACHAKA, S. K. ${ }^{3}$ \\ ${ }^{I}$ School of Forestry, Northeast Forestry University, Harbin 150040, Heilongjiang, P.R. China \\ ${ }^{2}$ Key Laboratory of Sustainable Forest Ecosystem Management - Ministry of Education, School \\ of Forestry, Northeast Forestry University, Harbin 150040, Heilongjiang, P.R. China \\ ${ }^{3}$ Faculty of Agronomy, University of Kinshasa, 117 Kinshasa XI, Mont-Amba/Lemba, \\ Democratic Republic of Congo \\ *Corresponding author \\ e-mail:fanwy@163.com; phone/fax:+86-139-4605-5384 \\ (Received $14^{\text {th }}$ Dec 2019; accepted $22^{\text {nd }}$ May 2020)
}

\begin{abstract}
Current information on land use/land cover change and its future evolution is required to support land management planning and policymaking in most developing countries experiencing deforestation and land degradation. Here, we explore the land use/land cover change occurring between 1987 and 2019 in the Mambasa sector, located in the Democratic Republic of Congo, and used the cellular automata model to predict the 2035 land use/land cover. The results have shown that during the last 32 years, dense forest has lost approximately 5121.54 ha, while secondary forest, fallow land and fields and, built-up area have gained 1786.23 ha, 3140.46 ha and 194.85 ha respectively. The predicted land use/land cover for the year 2035 revealed that dense and secondary forests will continue to experience a decrease of $3.85 \%$ and $13.65 \%$ respectively, while built-up area and fallow land and fields will experience an increase of $6.9 \%$ and $34.25 \%$ respectively. However, the study revealed that the unsustainable agriculture system combined with wood energy and artisanal logging have led to land use/land cover change in Mambasa. To reduce deforestation in the region, it would be necessary to improve agricultural production system, diversify the income and provide others timber product sources.
\end{abstract}

Keywords: land cover, CA-ANN model, remote sensing, Mambasa

\section{Introduction}

For centuries, human beings have been destroying the natural resources in order to satisfy their food needs through agricultural activities (Houghton, 1994). It is true that, for several years, the increase of human populations leads to the increase of the demand in natural resources, resulting in land degradation (Wondie et al., 2011).

Ouedraogo et al. (2010) has reported that, in tropical regions, the conversion of the natural forest areas to farmlands for the purpose of satisfying the increasing human population demand for natural resources makes agricultural activities one of the main causes of land degradation. Currently, land use/land cover change has been known for their negative effects on the survival of humankind. Indeed, in most cases, Land use/ land cover change strongly impacts crucial aspects of the functioning of the Earth (Lambin et al., 2001), especially with regard to their negative consequences on climate change (Song et al., 2018; Fan, 2015; Salazar et al., 2015; Houghton et al., 2017), degradation of soil (Alemu, 2015), global biogeochemical cycles such as carbon, nitrogen and water quality (Jain et al., 2013; Copeland et al., 1996; Schönhart et al., 2018; Le Maire et al., 2014; Spera et al., 2016; Sterling et al., 2013) as well as 
biodiversity loss (Haines-Young, 2009; Mantyka-Pringle et al., 2015; Wanger et al., 2010). Consequently, land use/land cover change has become one of the key environmental issues, specifically in tropical regions where deforestation is taking place at a rapid rate (Scholes and Van Breemen, 1997). Thus, performing studies on land use/ land cover change issues in these regions is important to reduce their negative consequences on humankind, and to assure the long-term persistence of natural resources.

According to Lambin et al. (2001), land cover points to the actual biophysical attributes of the Earth's surface (vegetation type, presence of water, rocks) whereas land use refers to the way in which the land cover is used. Thus, for numerous applications such as vegetation and farmland monitoring, analysis of the Earth's surface and atmosphere interactions, information on the current status of the land use/land cover is necessary (Townshend, 1992). Therefore, for the purpose of establishing sustainable land use policy with regard to natural resources, understanding the dynamics of the landscape is most important for development planners to suggest some good strategies to the current land-use for better management of natural resources and, to avoid some future unwanted negative consequences on humankind. In this context of spatiotemporal analysis, remote sensing technology can play a leading role in the frame of land use/land cover change monitoring.

Remotely sensed data, especially landsat images, have been extensively used in the frame of modeling land use/land cover change for different purposes (Ranagala et al., 2019; Song et al., 2018; Han et al., 2015; Simwanda et al., 2018; Rogan and Chen, 2004; Wu et al., 2006; Zhuravleva et al., 2013; Potapov et al., 2012; Chen et al., 2018). Indeed, for several decades, remote sensing combined with field measurements have been used with success to monitor the loss of forest cover all over the world (Defries et al., 2006). In addition, remote sensing technology possesses not only the capability to capture land use/land cover change information using different change detection techniques (Roy et al., 2002), but also, the ability to offer spatial information and repeated coverage of large areas (Lillesand et al., 2004).

Among numerous tools used for the purpose of modelling and predicting land use/land cover change, the Markov chain has not only been proved to be one of the powerful tools, but also delivered accurate results in the frame of land use/land change prediction (Halmy et al., 2015; Agarwal et al., 2002). Being a stochastic model, the Markov chain approach predicts the future evolution of one system based on the state of the initial time (Sinha and Kimar, 2013; Muller and Middleton, 1994). Numerous studies have used the Markov Cellular automata (CA) approach to predict land use/land cover change (Basse et al., 2014; Saputra et al., 2019; Li and Yeh, 2002; Nouri et al., 2014; Kumar et al., 2014; Mubea et al., 2010; Rendana et al., 2015). From these studies, it has been shown that Markov chain constitutes one of the most essential tools for land use planning and environmental change research over different regions of the world. The use of both stochastic Markov techniques and the cellular automata model seems to predict land use change better than the regression based models (Ye and Bai, 2008; Pontius and Malanson, 2005).

There are numerous tools used to model and predict land use/land cover change, but it seems that no research has been carried out to examine the land use/land cover change of the Mambasa sector, even though this region, located in amongst forested areas of the Democratic Republic of Congo, where pressures on forests are ever increasing, still experience accelerated land degradation, biodiversity loss, and climate change. And yet, 
accurate and current information on land use/land cover change is important to provide valuable information to decision-makers for elaborating good policies and strategies of sustainable forest management in Mambasa. Indeed, the assessment of the landscape dynamic due to human activities can provide the status of each land use/land cover type and its recent evolution so that further decision making processes can be initiated to undertake sustainable land use management Thus, the objectives of this study are (i) to analyze the spatio-temporal change of land use/land cover change of Mambasa sector from the year 1987 to 2019 and, (ii) to predict the future land use/land cover of the year 2035 using CA-ANN model.

\section{Materials and methods}

\section{Study area}

This study was conducted in Mambasa, an administrative sector of the Democratic Republic of Congo. It is located between $1^{\circ} 7^{\prime} 0^{\prime \prime}-1^{\circ} 29^{\prime} 0^{\prime \prime} \mathrm{N}$ in latitude and $28^{\circ} 53^{\prime} 0^{\prime \prime}$ $29^{\circ} 7^{\prime} 0^{\prime \prime} \mathrm{E}$ in longitude (Fig. 1). Its total land area is estimated at 45669.24 ha, entirely located in the Congolese central basin. The region is dominated by dense rainforest and equatorial climate. This climate is characterized by two dry seasons, notably the long dry season (between January and February) and the small dry season (between June and August). Over the two last decades, Mambasa has experienced considerable population growth that has negatively impacted its natural resources. Consequently, careful assessment of land use/land cover change is required to help decision makers for the purpose of elaborating sustainable land management planning of natural resources.

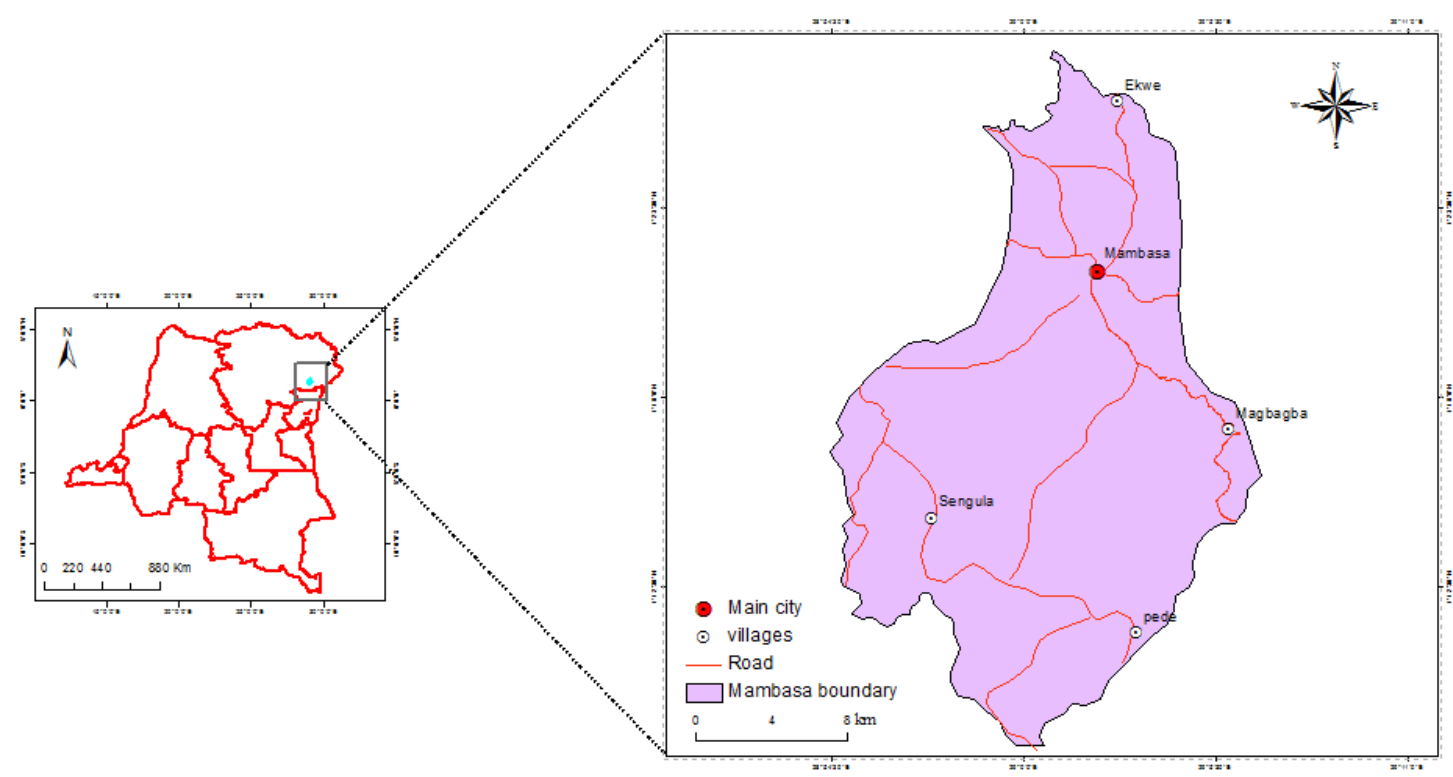

Figure 1. Location of Mambasa sector in the Democratic Republic of Congo

\section{Data collection}

According to the Landsat Worldwide Reference System (WRS), Mambasa is located at the Path and Row position of 174 and 59, respectively. Thus, Landsat images of the year 1987, 2003 and 2019, were freely downloaded from the website of the US 
Geological Survey National Center for Earth Resources Observation and Science (http://glovis.usgs.gov/2, in order to extract crucial information on land use/land cover change in the Mambasa sector. In addition, as it requires to better know the region before performing supervised classification, field observations were carried out during March 2019 for the purpose of understanding the characteristics of each land use/land cover category. Thus, for each land use/land cover class, 150 training reference points were collected using the GPS receiver. The three landsat images were acquired in March and February because of cloud free images or clear sky during that period (Table 1). Indeed, using satellite images acquired almost in the same period remains an important advantage of land use/land cover change study. This removes the effects of change in season when investigating year-to-year change, and also minimizes the discrepancies in reflectance caused by seasonal vegetation fluxes, climatic differences and sun angle differences (Singh, 1989).

Table 1. Characteristics of remotely sensed data used for the study

\begin{tabular}{c|c|c|c|c|l}
\hline Sensors & Acquisition date & Spatial resolution & Path/row & Band combination & Source \\
\hline LT05 & March 1987 & $30 \mathrm{~m}$ & $174 / 59$ & $5,4,3$ & http://glovis.usgs.gov/. \\
LE07 & February 2003 & $30 \mathrm{~m}$ & $174 / 59$ & $5,4,3$ & http://glovis.usgs.gov/. \\
LC08 & March 2019 & $30 \mathrm{~m}$ & $174 / 59$ & $6,5,4$ & http://glovis.usgs.gov/. \\
\hline
\end{tabular}

\section{Land use/land cover classification and change detection}

After performing the image preprocessing (radiometric calibration and atmospheric correction using the FLAASH method), we then carried out supervised classification of the 1987, 2003 and 2019 satellite images following the Yangambi vegetation classification system. Firstly, field data was collected for each land use/land cover class in order to identify the spectral signature of each one (Fig. 2). In addition, using the maximum likelihood algorithm, satellite images were classified into four categories, namely dense forest, fallow land and fields, secondary forest and built-up area. In fact, the maximum likelihood algorithm is a parametric decision whose rule is based on the probability that has a certain pixel belonging to a certain category. It has been reported that this algorithm provides the higher classification accuracy in land use/land cover study (Vadrevu, 2013). Ultimately, post-classification operations were applied to improve the classified images. For our research, different software were applied as each one has its strength in certain operations needed for analysis. All image processing (image preprocessing and classification, change detection and accuracy assessment) were performed in ENVI 5.3 software and QGIS, while ArcGIS 10.1 was used to produce the final map.

To describe land cover change occurring between 1987 and 2019, the transition matrix method was applied. The transition matrix corresponds to a squared matrix describing changes occurring on different elements of a system during a certain period (Bell, 1974). Cells of matrix contain values of the variable which changed the state from initial time to final time. Values of column and rows represent the proportion of an area occupied by each land cover class at the corresponding time.

Figure 3 shows the overall workflow of the study, including all the different steps from data collection to the production of the predicted land use/cover map. 


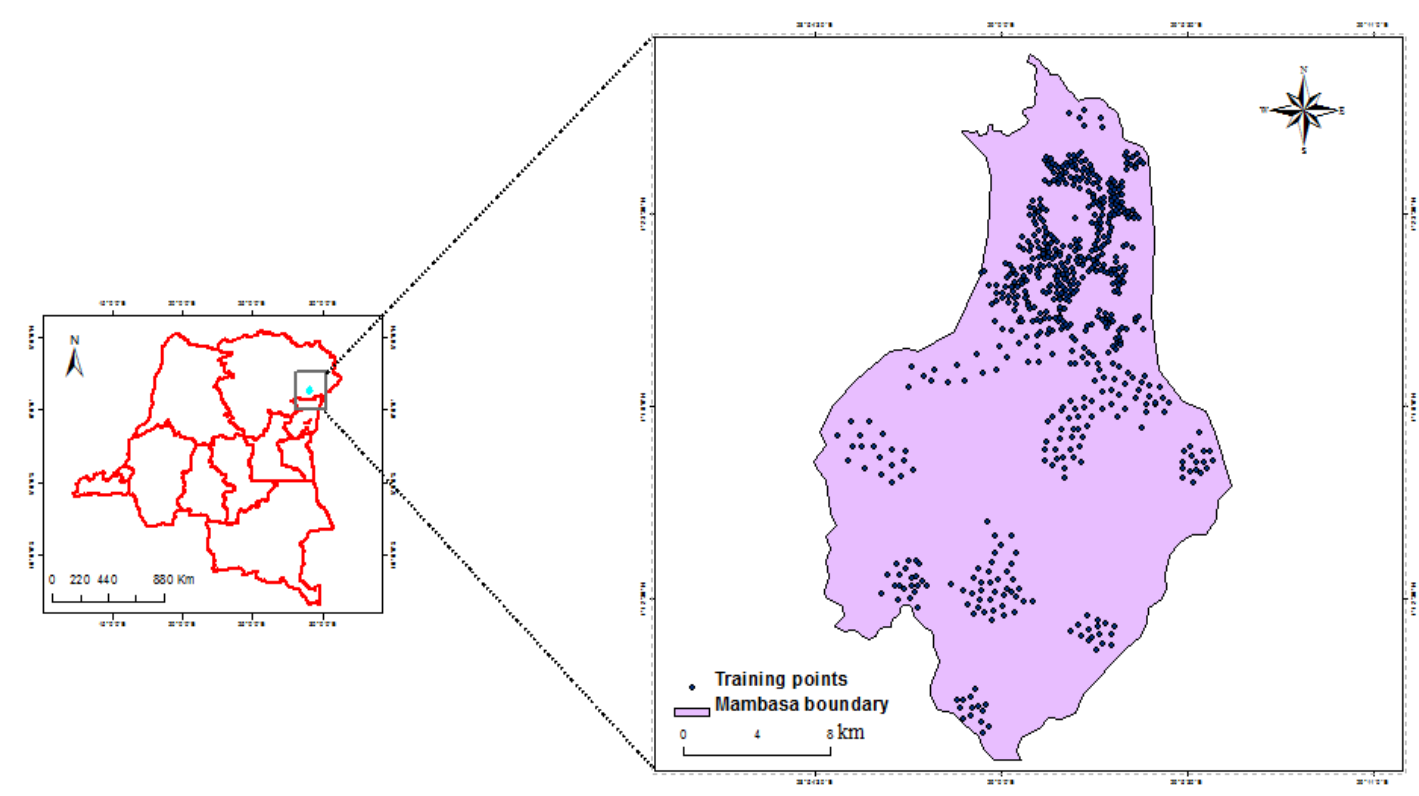

Figure 2. Location of training reference points collected during the field survey in the Mambasa sector

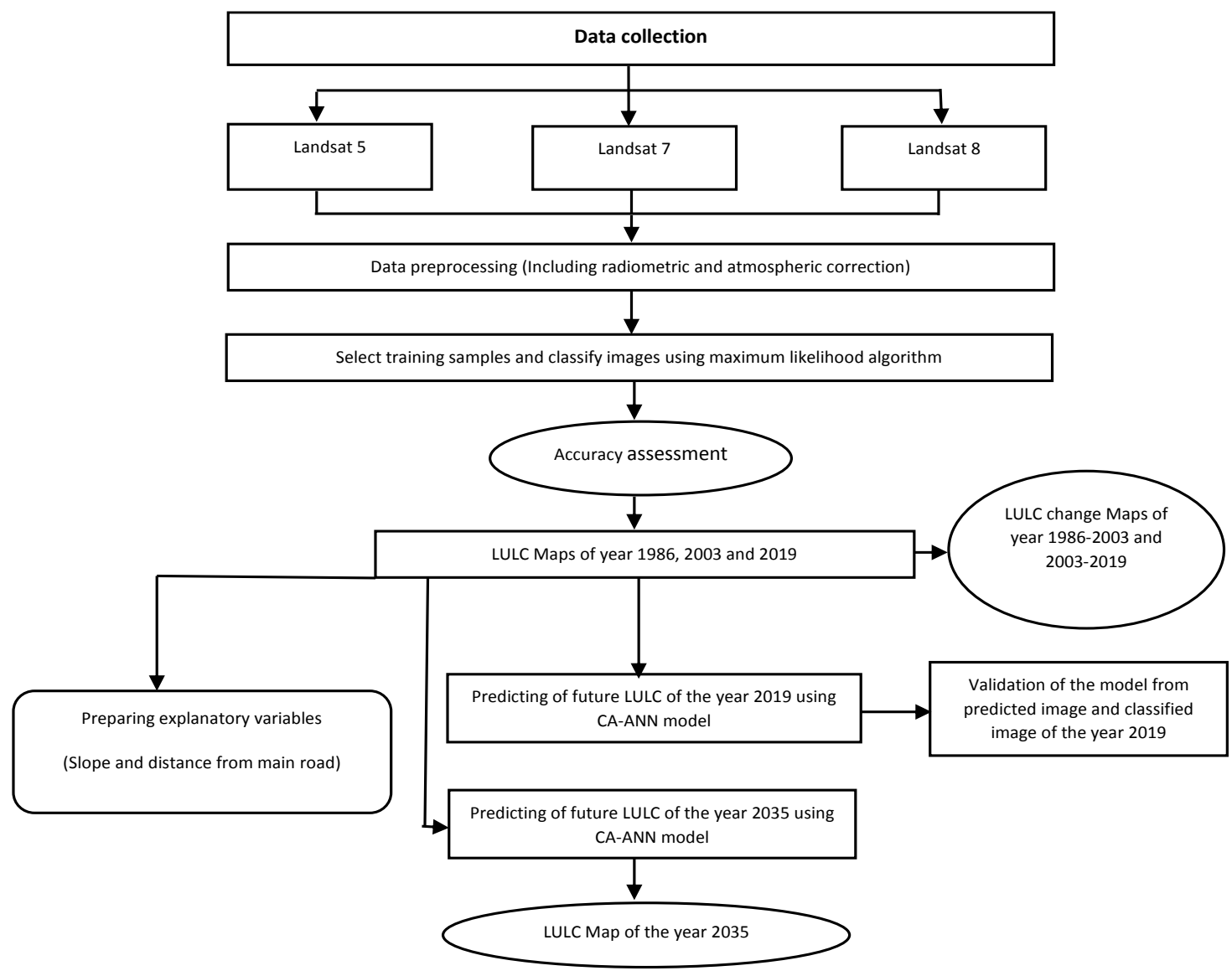

Figure 3. Schematic diagram of the research approach

\section{Prediction of future land use/land cover change}


For the purpose of predicting land use/land cover change in the Mambasa sector, MOLUSCE plugin imbedded in QGIS software was used. The cellular automata (CA) model was then applied, and the artificial neural network (ANN) algorithm was used in the model. Indeed, Jogun (2019) has stated that the use of the machine learning algorithm such as ANN to predict land cover change, is better than other methods like linear regression. Thus, two explanatory variables namely slope and distance from main roads in the Mambasa sector, were used in order to predict the future change. Firstly, the 1987 and 2003 classified images were used to predict the 2019 land use/land cover. Then, the three map comparison method was performed for the validation of the prediction results. As the validation results have shown high accuracy, the 2035 land use/land cover was predicted by means of 2003 and 2019 classified images.

Figure 4 describes the structure of the CA-ANN model. Neurons in the input layers are considered as a set of cellular attributes, which are explanatory variables (slope and distance from main roads). It was reported that these variables explained the land use/land cover change probabilities. In the output layer, a neuron relates to a land use/land cover category. Each neuron value in the output layer represented the transition probability from the existing class to the corresponding land use class.

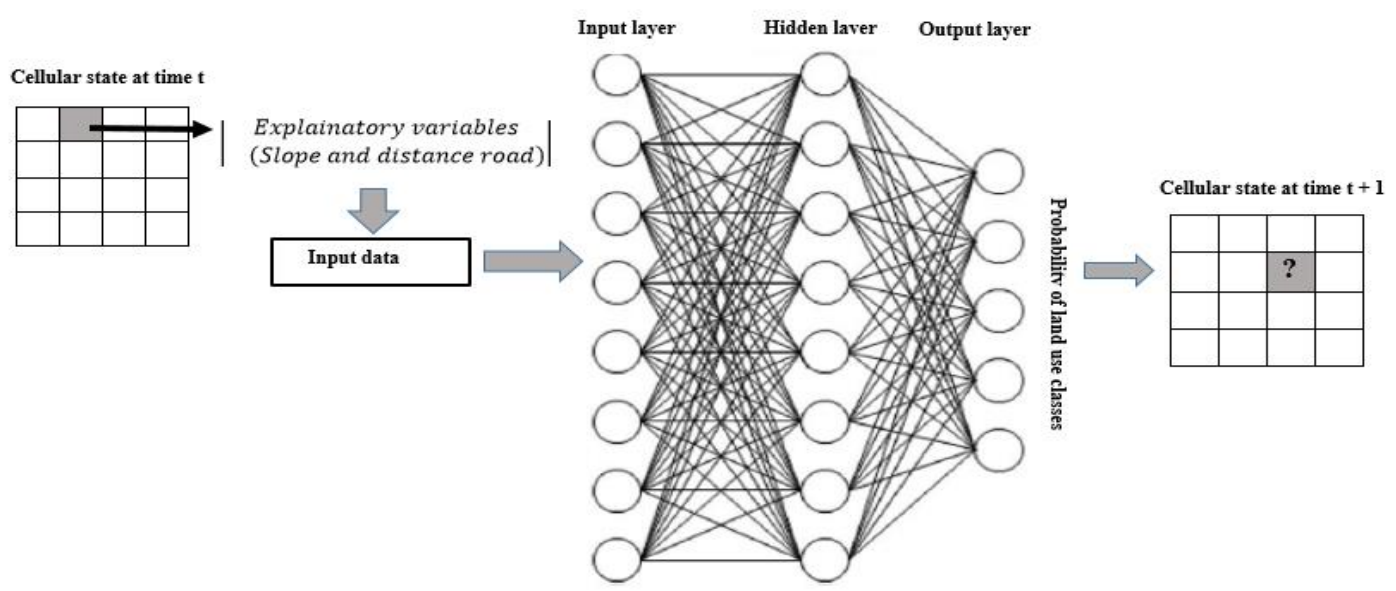

Figure 4. Processing architecture of ANN-CA model

\section{Accuracy assessment}

To use a land use/land cover map, it is crucial to know the accuracy of the map (Plourde and Congalton, 2003; Smits et al., 1999). Thus, accuracy assessment for the 1987, 2003 and 2019 maps was performed to appreciate the quality of information resulting from the image classification process. The confusion matrix method, which is the most common approach for appreciating image classification accuracy, was applied (Congalton, 1991). In this article, the reference data (ground truth points) were collected in March 2019 to perform the accuracy assessment of the 2019 classified image, while Google earth was used to carry out accuracy assessment for the 1986 and 2035 classified images. We then compared the observed pixels (ground truth points) of every land use/land cover class to the map pixel. The results were generated into the confusion matrix in order to assess the 1987, 2003 and 2019 final land use/land cover map accuracy. The overall user's and producer's accuracies were calculated from the confusion matrix. According to Pontius and Millones (2011), the producer's accuracy is 
used for determining how well an image is classified. In addition, the Kappa coefficient, one of the most statistic parameter for assessing image classification accuracy, was also computed (Rosenfield and Fitzpatrick-Lins, 1986).

Therefore, the overall accuracy of classification for the 1987, 2003 and 2019 map are $88.16 \%$ (kappa value 0.85), 89.16\% (kappa value 0.86) and 93.6\% (kappa value 0.91), respectively. As noted by (Weng, 2002), the minimum level for accuracy assessment in identification of land use/ land cover categories in the field of remote sensing should be at least $85 \%$.

\section{Results}

\section{Accuracy assessment of satellite image classification}

The land use/land cover classification was successfully carried out with a high accuracy level. The overall accuracy of the 2019, 2003 and 1987 maps are 93.6\% (kappa value 0.91), 89.15\% (kappa value 0.86) and 88.16\% (kappa value 0.85), respectively.

For the 2019 map, error matrix has been presented in Table 2. 159 of 170 field samples were correctly classified. The main confusion was observed between dense forest and secondary forest, with four validation points on secondary forest classified as dense forest, while two validation points on dense forest were classified as secondary forest. In addition, two validation points in secondary forest were classified as fallow land and field, while one validation point in the built-up area was classified as secondary forest.

For the 2003 map, error matrix has been presented in Table 3. A total of 218 reference points were checked against Google Earth image.196 of 218 validation samples were correctly classified. The main confusion was observed between dense forest and secondary forest, with seven validation points on secondary forest classified as dense forest, while six validation points in dense forest were classified as secondary forest. In addition, one validation point in secondary forest was classified as fallow land and field, while two validation points in fallow land were classified as secondary forest. Three validation points in fallow land were classified as built-up area, and three validation points in the built-up area were classified as fallow land and fields.

Table 2. Error matrix of land cover map produced by supervised classification of 2019 image

\begin{tabular}{|c|c|c|c|c|c|c|}
\hline Number of pixels & \multicolumn{5}{|c|}{ Reference data } & \multirow{2}{*}{ User's accuracy $(\%)$} \\
\hline Classified image & DF & SF & FF & BA & Row total & \\
\hline DF & 61 & 2 & 0 & 0 & 63 & 96.3 \\
\hline SF & 4 & 42 & 2 & 0 & 46 & 91.3 \\
\hline FF & 0 & 0 & 34 & 2 & 39 & 92.3 \\
\hline BA & 0 & 1 & 0 & 22 & 24 & 91.7 \\
\hline Column total & 65 & 45 & 36 & 24 & & \\
\hline Producer's accuracy (\%) & 93.9 & 93.3 & 94.7 & 91.7 & & \\
\hline
\end{tabular}

Overall accuracy: 93.6, Kappa statistic: 0.91

Table 3. Error matrix of land cover map produced by supervised classification of 2003 image 


\begin{tabular}{|c|c|c|c|c|c|c|}
\hline \multirow{2}{*}{$\begin{array}{l}\text { Number of pixels } \\
\text { Classified image }\end{array}$} & \multicolumn{5}{|c|}{ Reference data } & \multirow[b]{2}{*}{ User's accuracy $(\%)$} \\
\hline & DF & SF & FF & $\mathbf{B A}$ & Row total & \\
\hline $\mathrm{DF}$ & 68 & 6 & 0 & 0 & 74 & 91.9 \\
\hline SF & 7 & 52 & 1 & 0 & 60 & 86.7 \\
\hline FF & 0 & 2 & 48 & 3 & 53 & 90.6 \\
\hline BA & 0 & 0 & 3 & 28 & 31 & 90.3 \\
\hline Column total & 75 & 60 & 52 & 31 & & \\
\hline Producer's accuracy (\%) & 90.7 & 86.7 & 92.3 & 90.3 & & \\
\hline
\end{tabular}

Overall accuracy: 89.16 , Kappa statistic: 0.86

DF: dense forest, SF: secondary forest, FF: fallow land and fields, BA: built-up area

\section{Spatial and temporal changes in land use/land cover}

Summary statistics of Land use/land cover change for the Mambasa sector for the years 1987, 2003 and 2019 developed from supervised classification are listed in Table 4.

Table 4. Evolution of land use/cover in Mambasa sector from 1987 to 2019

\begin{tabular}{c|c|c|c|c|c|c|c}
\hline \multirow{2}{*}{$\begin{array}{c}\text { Land use/cover } \\
\text { classes }\end{array}$} & \multicolumn{5}{|c|}{ Spatial area coverage } & $\begin{array}{c}\text { Annual rate } \\
\text { of change }\end{array}$ \\
\cline { 2 - 8 } & \multicolumn{2}{|c|}{$\mathbf{1 9 8 7}$} & \multicolumn{2}{c|}{$\mathbf{2 0 0 3}$} & \multicolumn{2}{|c|}{$\mathbf{2 0 1 9}$} & $\mathbf{1 9 8 7 - 2 0 1 9}$ \\
\cline { 2 - 8 } & Area (ha) & $\%$ & Area (ha) & $\%$ & Area (ha) & \% & ha/year \\
\hline Built-up area & 302.76 & 0.66 & 412.02 & 0.9 & 497.61 & 1.09 & 6.09 \\
Fallow land and fields & 2763.99 & 6.05 & 4149.36 & 9.09 & 5904.45 & 12.93 & 98.14 \\
Secondary forest & 3753.54 & 8.22 & 5804.01 & 12.71 & 5539.77 & 12.13 & 55.82 \\
Dense forest & 38848.95 & 85.07 & 35303.85 & 77.3 & 33727.41 & 73.85 & -160.05 \\
\hline Total & 45669.24 & 100 & 45669.24 & 100 & 45669.24 & 100 & \\
\hline
\end{tabular}

During our survey, Mambasa sector's landscape was classified into four land cover/land use types including dense forest, Secondary forest, Fallow land and fields, and built-up area (Fig. 5). On the basis of analysis carried out in 1987, it was noted that approximately $85.07 \%, 8.22 \%, 6.05 \%$ and $0.66 \%$ of the total area subject to analysis were calculated as dense forest, Secondary forest, Fallow land and fields, and built-up areas, respectively; while, in 2003, around $77.3 \%, 12.71 \%, 9.09 \%$ and $0.9 \%$ of the total area was calculated as dense forest, Secondary forest, Fallow land and fields, and builtup areas, respectively. In 2019, 73.85\%, 12.13\%, $12.93 \%$ and $1.09 \%$ were classified as dense forest, Secondary forest, Fallow land and fields, and built-up areas, respectively. Consequently, the land use/land cover change from 1987 to 2019 have shown an increasing in Secondary forest, Fallow land and fields, and built-up areas, by 1786.23 ha, 3140.46 ha, and 194.85 ha respectively; while in the same period dense forest underwent significant negative change. Indeed, dense forest land has strongly declined in the same period. Approximately 160.05 ha of dense forests were converted every year into other land use/land cover categories during the study period. However, the main change during the study period in the Mambasa sector was observed in the area converted from dense forest into Fallow land and fields. 

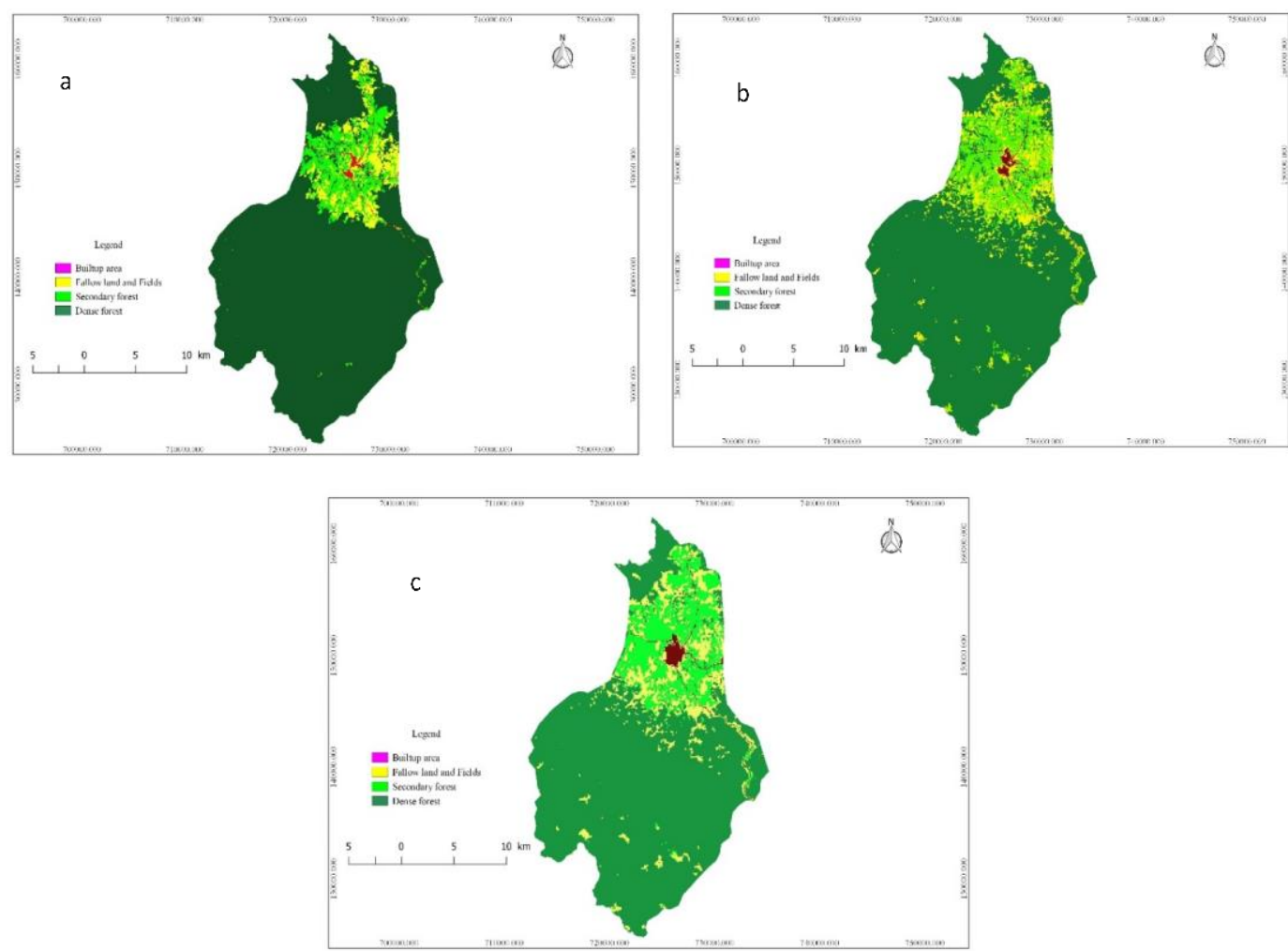

Figure 5. Land use/land cover map for the year (a) 1987, (b) 2003 and (c) 2019

\section{Transition among land use/land cover types from 1987 to 2019}

From the transitional probability matrix, it is easy to understand the trend in land use/land cover change occurring in the Mambasa sector during the study period. Indeed, the transitional probability matrix shows the probability of each cell of a certain land use/land cover type to be transformed into other types. Using the Markovian approach, the transitional probability matrix between the years 1987 to 2003, 2003 to 2019, and 1987 to 2019 has been performed in the MOLUSCE plugin. From Table 5, it can be revealed that, between 1987 and 2003, the probability of each land use/land cover category to be converted into fallow land and fields was higher than any other transition (third column). Moreover, it should be noted that, the conversion from dense forests to secondary forests is seen firstly as a conversion of dense forest into fallow land and fields; but when this land use/land cover class (fallow land and fields) is abandoned, it progresses into secondary forest by the natural process of vegetation succession. In addition, the no conversion from built-up area into dense forest was represented by zero values between 1987 and 2003, while, from 2003 to 2019, zero values represent no conversion of dense forest into built-up area. Figure 6 represents the change maps that shows the transformation from one land use/land cover class to the others during 1987 to 2019. From the change maps, it was shown that the major part of the Mambasa landscape was converted into fallow land and fields. A total of 37426.05 ha of our study area did not change between 1987 and 2019. Among them, 33495.56 ha persisted as dense forest, 2356.01 ha as secondary forest, 1381.44 ha as fallow land and fields and 192.95 ha as built-up area. On the other hand, around 3325.47 ha, 1117.80 ha, and 81.26 ha of our study area 
were converted from dense forest, secondary forest, and built-up area respectively into fallow land and fields during 1987 to 2019.

Table 5. Transition matrix of land use/cover changes in Mambasa sector from 1987 to 2019

\begin{tabular}{l|c|c|c|c|c}
\hline & \multicolumn{5}{c}{ Land cover category } \\
\cline { 2 - 6 } & From & Built-up area & Fallow \& fields & Secondary forest & Dense forest \\
\hline \multirow{3}{*}{$1987-2003$} & Built-up area & 0.7155 & 0.1813 & 0.1031 & 0.0000 \\
& Fallow and fields & 0.0440 & 0.4007 & 0.5314 & 0.0239 \\
& Secondary forest & 0.0112 & 0.2032 & 0.6717 & 0.1139 \\
& Dense forest & 0.0008 & 0.0573 & 0.0459 & 0.8960 \\
\hline \multirow{3}{*}{$2003-2019$} & Built-up area & 0.8746 & 0.0799 & 0.0443 & 0.0011 \\
& Fallow and fields & 0.01997 & 0.9290 & 0.0292 & 0.0216 \\
& Secondary forest & 0.0092 & 0.1809 & 0.7377 & 0.0722 \\
& Dense forest & 0.0000 & 0.0274 & 0.0317 & 0.9409 \\
\hline \multirow{2}{*}{$1987-2019$} & Built-up area & 0.6373 & 0.2684 & 0.0859 & 0.0083 \\
& Fallow and fields & 0.0559 & 0.4998 & 0.4251 & 0.0193 \\
& Secondary forest & 0.0280 & 0.2978 & 0.6277 & 0.0465 \\
& Dense forest & 0.0012 & 0.0856 & 0.0510 & 0.8622 \\
\hline
\end{tabular}
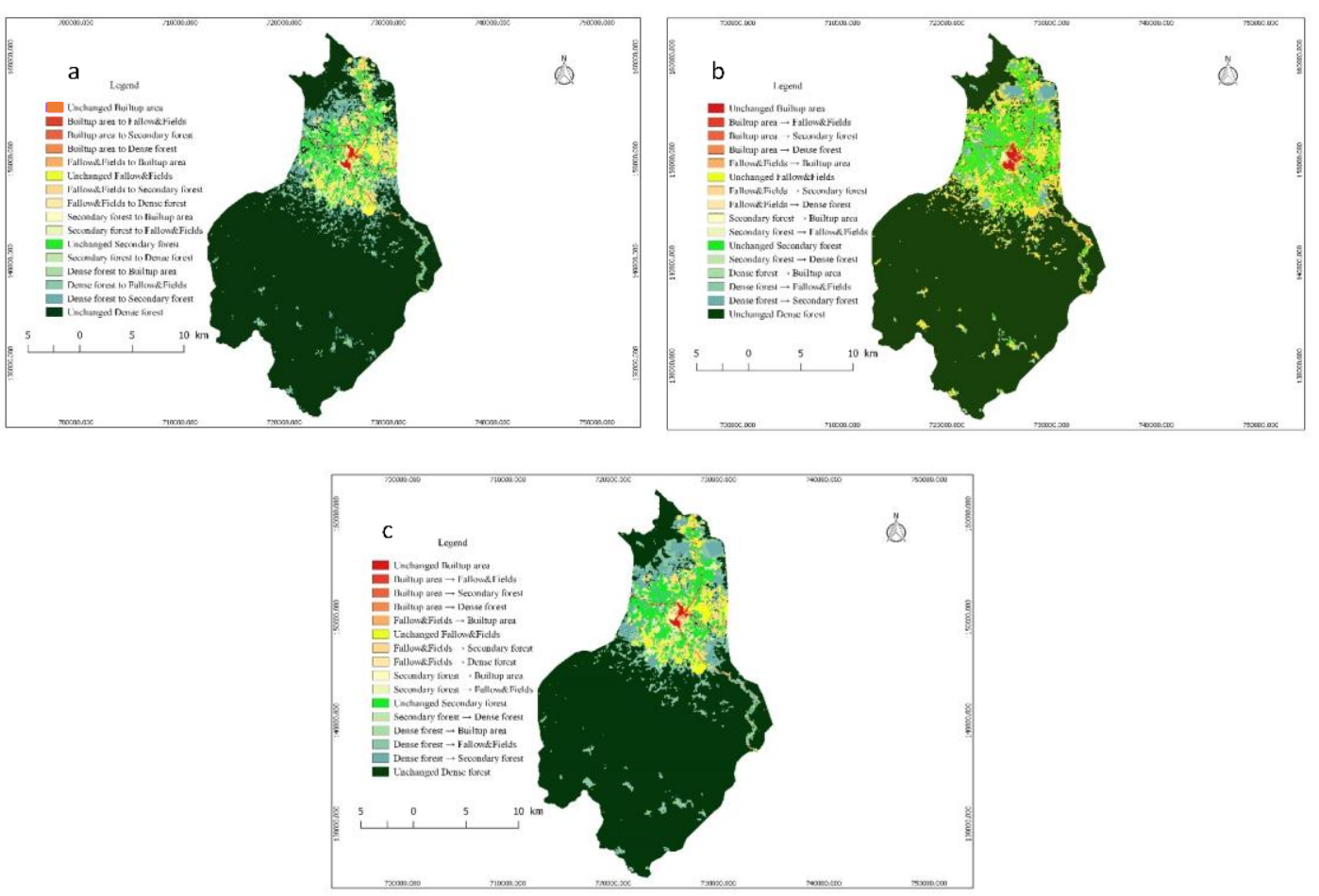

Figure 6. LULC transformation of Mambasa sector during (a) 1987 to 2003, (b) during 2003 to Prediction of the future land use change 2035 2019 and (c) during 1987 to 2019

After performing the change detection analysis, the next step of this study was focused at forecasting the future land use/land cover for the year 2035. Thus, the simulated map of 2035 as shown in Figure 7 was carried out using two spatial drivers 
including slope and distance from main roads. Firstly, the land use/land cover for the year 2019 was predicted by using both land use/land cover maps of the year 1987 and 2003, by means of the Cellular automata Artificial Neural Network (CA-ANN) algorithm. Then, the three map comparison method was applied to validate the prediction results. It has been demonstrated that the model, by its strong performance measured by the percentage of component agreement at $97.3 \%$, was able to predict the future land use/land cover change almost correctly. After the validation of the model, the land use/land cover for the year 2035 was predicted from the year 2003 to 2019. In 2035, Mambasa sector will have an increase in Fallow land and fields (34.25\% ha) and built-up area $(6.9 \% \mathrm{~h})$, while dense and secondary forest will lose $3.85 \%$ and $13.65 \%$ respectively (Table 6).

Table 6. Summary of LULC change statistics between 2019 and 2035

\begin{tabular}{c|c|c|c}
\hline \multirow{2}{*}{ LULC classes } & \multicolumn{2}{|c|}{ Area in hectare } & \multirow{2}{*}{ Area change from 2019 to 2035 in (\%) } \\
\cline { 2 - 3 } & $\mathbf{2 0 1 9}$ & $\mathbf{2 0 3 5}$ & 6.9 \\
\hline Built-up area & 497.61 & 531.90 & 34.25 \\
Fallow \& fields & 5904.45 & 7926.48 & -13.65 \\
Secondary forest & 5539.77 & 4783.50 & -3.85 \\
Dense forest & 33727.41 & 32427.36 & \\
\hline
\end{tabular}

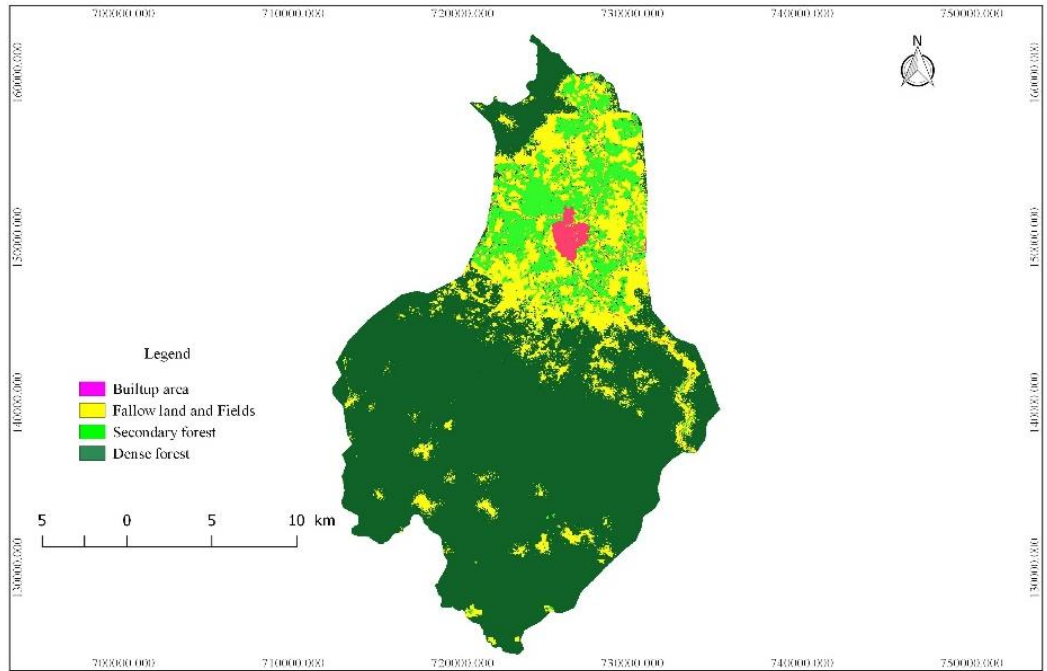

Figure 7. Predicted LULC for the year 2035

\section{Discussion}

\section{Land use/land cover change from the year 1987 to 2019 and future prediction of 2035}

The present study aimed to assess the land use/land cover change in the Mambasa sector from 1987 to 2019, and predict the spatio temporal change by 2035 using the Cellular automata Artificial Neural Network (CA-ANN) algorithm. The results revealed significant change in Mambasa's landscape during the study period. Indeed, Mambasa's landscape was classified into four categories namely dense forest, secondary forest, built-up areas as well as fallows and fields. During the last 32 years, dense forest has approximately lost 5121.54 ha, while secondary forest, fallow land and fields, built-up 
area have gained 1786.23 ha, 3140.46 ha and 194.85 ha respectively. The ratio of dense forest in the landscape declined from $85.07 \%$ in 1987 , to $73.85 \%$ in 2019 . Thus, the annual rate of deforestation observed in dense forest was estimated at 0.41 . This rate is well above the national average, estimated between 0.2 and $0.3 \%$ over the last three decades (UN-REDD, 2012; de Wasseige et al., 2014). As for secondary forest, its area has also increased during the last three decades, from 3753.54 ha in 1987 to 5539.77 ha in 2019. Note that most of its area comes from dense forest that has been converted into fallow land and fields and, after being abandoned, it evolved to secondary forest through the natural process of succession vegetation. Fallow land and fields showed a positive evolution following the acquisition of areas mainly lost in dense and secondary forests, respectively 3325.47 ha and 1117.8 ha. Its proportion in the landscape increased from $6.05 \%$ in 1987 , to $12.93 \%$ in 2019 . This can be explained by the expansion of agricultural activities in this region and the increase of population in the region (Table 7). As reported by (Aweto, 2012), in the humid and sub-humid tropics, several hundred million people depend on agriculture system based on shifting cultivation or rotational bush fallowing for their livelihood. Indeed, agriculture system in Mambasa is based on shifting cultivation that consists in clearing primary or secondary forest to install fields. These fields can be cultivated for one or two years before soil fertility is exhausted. The field is then abandoned and the farmers move on to clear a new field elsewhere in the forest. Bamba (2010) has stated that, agriculture of DRC based on the slash-and-burn agriculture system has always been practiced for several decades. In addition, (Mpoyi et al., 2013) noted that the agriculture system in this region is based on unimproved varieties and unsustainable practices of soil fertility management. Consequently, several hectares of forest are lost every year for the benefit of crop land. Our results corroborate the findings of (Ngabinzeke et al., 2016) that reported that the expansion of slash-and-burn agriculture in the region is leading to a conversion of natural habitats. According to the study, significant changes occurred during a period of one year in the area under study. Forest and savanna areas declined by 6.5 ha (86.6 to 80.1 ha) while agricultural areas (cleared land and seasonal crops) increased from 7.3 ha to 21.8 ha. Similar results were obtained in a study conducted in the Kongo central province. In this study, it has been reported that fallow land and fields increased from $22.72 \%$ in 1960 to $54.61 \%$ in 2005 ; while forest land, the landscape's matrix in 1960 , declined from $49.95 \%$ of the total area of landscape to $5.67 \%$ in 2005 . The study has revealed that the decrease in forest area was due to the unsustainable agriculture system and demographic pressures (Bamba, 2010). In a study conducted in Isangi region, it was found that due to human activities, notably agriculture and forest logging for wood energy, the percentage of forest land decreased by 20.9\% (59 004 ha to 46675 ha) during 2002-2010, while mosaic habitat-agriculture land increased by $24 \%$ (23191 ha to 28768 ha) during 2002-2010 (Ciza et al., 2015).

However, the predicted change in 2035 shows that, there will still be an increase in Fallow land and fields and Builtup area, while dense and secondary forest will experience a decrease by 1300.05 ha and 756.27 ha, respectively. The decrease in secondary forest can be attributed to the expansion of agriculture in that land cover category. In fact, after several years, secondary forest appear to be suitable for developing agriculture as well as dense forest. The decrease in dense forest can also be explained by the expansion of human activities such as agriculture, wood energy and logging. 
Table 7. Evolution of population of the Mambasa sector from 1987 to 2019

\begin{tabular}{c|c}
\hline Year & Population \\
\hline 1987 & 55000 \\
2003 & 128000 \\
2019 & 249369 \\
\hline
\end{tabular}

\section{Model validation}

The present study used the three map comparison method to evaluate the model performance for land use/land cover change simulation in Mambasa sector. This approach was proposed by Pontius et al. (2011), and consists of two components of agreement and three components of disagreement (Bayes and Raquib, 2012). Indeed, the components of agreement include persistence simulated correctly (correct rejection) and change simulated correctly (hits), while the components of disagreement contain change simulated as persistence (misses), persistence simulated as change (false alarm), and change simulated as change to wrong category (Wrong hits). After implementing the three-map comparison method, it has been revealed that the simulated map yields the best result in terms of the percentages of component disagreement $(2.3 \%)$ and component agreement $(97.7 \%)$, as presented in Table 8.

Table 8. Components of agreement and disagreement of three map comparison method

\begin{tabular}{c|c}
\hline Name of component & \% \\
\hline Persistence simulated correctly & 96.13406 \\
Change simulated correctly & 1.534867 \\
Total agreement & 97.66893 \\
Change simulated as persistance & 0.423469 \\
Persistence simulated as change & 0.737927 \\
Change simulated as to wrong category & 1.169677 \\
Total disagreement & 2.331073 \\
\hline
\end{tabular}

\section{Conclusions}

The land use/cover change caused by direct and indirect human activities has negative consequences at spatial and temporal scales. Understanding those changes provides relevant knowledge that is most important for decision-makers and civil society. This study examines land use/cover change in the Mambasa sector between 1987 and 2019, and uses CA-ANN to predict the future land cover change by 2035. During the last 32 years, It was shown that dense forest has approximately lost 5121.54 ha, while secondary forest, fallow land and fields, built-up area have gained 1786.23 ha, 3140.46 ha and 194.85 ha, respectively. The ratio of dense forest in the landscape declined from $85.07 \%$ in 1987 , to $73.85 \%$ in 2019 . Thus, the annual rate of deforestation observed in dense forest was estimated at $0.41 \%$. From the change occurred in Mambasa landscape, it was revealed that the major part for the Mambasa landscape was converted into fallow land and fields. A total of 37426.05 ha for the Mambasa landscape were considered as persistence between 1987 and 2019. Among them, 33495.56 ha persisted as dense forest, 2356.01 ha as secondary forest, 1381.44 ha 
as fallow land and fields and 192.95 ha as built-up area. However, around 3325.47 ha, 1117.80 ha, and 81.26 ha were converted from dense forest, secondary forest, and builtup area into fallow land and fields during 1987 to 2019. The study revealed that the unsustainable agriculture system combined with wood energy and artisanal logging led to land use/cover changes in the Mambasa landscape. The predicted change in 2035 shows that, there will still be an increase in Fallow land and fields and built-up area, while dense and secondary forest will experience a decrease by 1300.05 ha and 756.27 ha, respectively. The decrease in secondary forest can be attributed to the expansion of agriculture in that land cover category. Hence, the present results should be taken into account to support sustainable management of Mambasa forest ecosystems and efficient use of natural resources. However, further studies on the effects of land use/land cover change on biodiversity composition, and the effects of climate change on it as well, should be undertaken to provide the whole vision of the phenomenon in the Mambasa sector.

Acknowledgements. This study was supported by The Fundamental Research Funds for the Central Universities (2572019CP12).

\section{REFERENCES}

[1] Agarwal, C., Green, G. M., Grove, J. M., Evans, T. P., Schweik, C. M. (2002): A Review and Assessment of Land-Use Change Models: Dynamics of Space, Time, and Human Choice. - Gen. Tech. Rep. NE-297. Department of Agriculture, Forest Service, Northeastern Research Station, Newtown Square, PA.

[2] Alemu, B. (2015): The effect of land use land cover change on land degradation in the highlands of Ethiopia. - Journal of Environment and Earth Science 5(1): 1-12.

[3] Aweto, A. O. (2012): Shifting Cultivation and Secondary Succession in the Tropics. CABI, Wallingford.

[4] Baillie, J., Hilton-Taylor, C., Stuart, S. N. (2004): 2004 IUCN red list of threatened species: a global species assessment. https://doi.org/10.2305/IUCN.CH.2005.3.en.

[5] Bamba, I. (2010): Anthropisation et dynamique spatio-temporelle de paysages forestiers en République démocratique du Congo. - Fac. des Sci. - Ec. Interfacultaire des Bioingénieurs.

[6] Basse, R. M., Omrani, H., Charif, O., Gerber, P., Bódis, K. (2014): Land use changes modelling using advanced methods: Cellular automata and artificial neural networks. The spatial and explicit representation of land cover dynamics at the cross-border region scale. - Geography 53: 160-171.

[7] Bayes, A., Raquib, A. (2012): Modeling urban land cover growth dynamics using multioral satellite images: A case study of Dhaka, Bangladesh. - ISPRS International Journal of Geo-Information 1(1): 3-31.

[8] Chen, J., Du, P., Wu, C., Xia, J., Chanussot, J. (2018): Mapping urban land cover of a large area using multiple sensors multiple features. - Remote Sensing 10(6): 872.

[9] Ciza, S. K., Mikwa, J. F., Malekezi, A. C., Gond, V., Bosela, F. B. (2015): Identification des moteurs de déforestation dans la région d'Isangi, République démocratique du Congo. - Bois Forets des Tropiques 324: 29-38.

[10] Congalton, R. G. (1991): A review of assessing the accuracy of classifications of remotely sensed data. - Remote Sensing of Environment 37: 35-46. 
[11] Copeland, J. H., Pielke, R. A., Kittel, T. G. F. (1996): Potential climatic impacts of vegetation change: a regional modeling study. - Journal of Geophysical Research Atmospheres 101(D3): 7409-7418.

[12] Defries, R., R., Achard, F., Brown, S., Herold, M., Murdiyarso, D., Schlamadinger, B. C. J. (2006): Reducing Greenhouse Gas Emissions from Deforestation in Developing Countries: Considerations for Monitoring and Measuring. - Report of the Global Terrestrial Observing System (GTOS), Report No. 46. GTOS, Rome.

[13] de Wasseige, C., Flynn, J., Louppe, D., Hiol, F., Mayaux (2014): The Forests of the Congo Basin: State of the Forest 2013. - Weyrich, Belgium. https://doi.org/10.2788/32259.

[14] Fan, M., Shibata, H. (2015): Simulation of watershed hydrology and stream water quality under land use and climate change scenarios in Teshio River watershed, northern Japan. Ecological Indicators 50: 79-89.

[15] Haines-Young, R. (2009): Land use and biodiversity relationships. - Land Use Policy 26: 178-186.

[16] Halmy, M. W. A., Gessler, P. E., Hicke, J. A., Salem, B. B. (2015): Land use/land cover change detection and prediction in the north-western coastal desert of Egypt using Markov-CA. - Applied Geography 63: 101-112.

[17] Han, H., Yang, C., Song, J. (2015): Scenario simulation and the prediction of land use and land cover change in Beijing, China. - Sustainability (Switzerland) 7(4): 4260-4279.

[18] Houghton, R. A. (1994): The worldwide extent of land-use change. - Bioscience 44: 305313.

[19] Houghton, R. A., Nassikas, A. A. (2017): Global and regional fluxes of carbon from land use and land cover change 1850-2015. - Global Biogeochemical Cycles 31(3): 456-472.

[20] Jain, A. K., Meiyappan, P., Song, Y., House, J. I. (2013): CO2 emissions from land-use change affected more by nitrogen cycle, than by the choice of land-cover data. - Global Change Biology 19(9): 2893-2906.

[21] Jogun, T., Lukić, A., Gašparović, M. (2019): Simulation model of land cover changes in a post-socialist peripheral rural area: Požega-slavonia county, Croatia. - Hrvatski Geografski Glasnik 81(1): 31-59.

[22] Kumar, S., Radhakrishnan, N., Mathew, S. (2014): Land use change modelling using a Markov model and remote sensing. - Geomatics, Natural Hazards and Risk 5(2): 145156.

[23] Lambin, E., Turner, B., Geist, H., Agbola, S., Angelsen, A., Bruce, J., Coomes, O., Dirzo, R., Fischer, G., Folke, C., George, P., Homewood, K., Imbernon, J., Leemans, R., Li, X., Moran, E., Mortimore, M., Ramakrishnan, P., Richards, J., Skånes, H., Steffen, W., Stone, G., Svedin, U., Veldkamp, T., Vogel, C., Xu, J. (2001): The causes of land-use and land-cover change: moving beyond the myths. - Global Environmental Change 11(4): 261-269.

[24] Le Maitre, D. C., Kotzee, I. M., O'Farrell, P. J. (2014): Impacts of land-cover change on the water flow regulation ecosystem service: invasive alien plants, fire and their policy implications. - Land Use Policy 36: 171-181.

[25] Li, X., Yeh, A. G. O. (2002): Neural-network-based cellular automata for simulating multiple land use changes using GIS. - International Journal of Geographical Information Science 16(4): 323-343.

[26] Lillesand, T. M., Kiefer, R. W., Chipman, J. W. (2004): Remote Sensing and Image Interpretation. - Wiley, New York.

[27] López, E., Bocco, G., Mendoza, M., Velázquez, A., Rogelio Aguirre-Rivera, J. (2006): Peasant emigration and land-use change at the watershed level: a GIS-based approach in Central Mexico. - Agricultural Systems 90(1-3): 62-78.

[28] Mantyka-Pringle, C. S., Visconti, P., Di Marco, M., Martin, T. G., Rondinini, C., Rhodes, J. R. (2015): Climate change modifies risk of global biodiversity loss due to land-cover change. - Biological Conservation 187: 103-111. 
[29] Mpoyi, A. M., Nyamwoga, F. B., Kabamba, F. M., Assembe-mvondo, S. (2013): Le contexte de la REDD+ en République Démocratique du Congo Causes, agents et institutions. - CIFOR, Bogor.

[30] Mubea, K. W., Ngigi, T. G., Mundia, C. N. (2010): Assessing application of markov chain analysis in predicting land cover change: a case study of Nakuru municipality. Journal of Agriculture, Science and Technology 12(2).

[31] Muller, M. R., Middleton, J. (1994): A Markov model of land-use change dynamics in the Niagara Region, Ontario, Canada. - Landscape Ecology 9(2): 151-157.

[32] Ngabinzeke, J. S., Linchant, J., Quevauvillers, S., Muhongya, J. M. K., Lejeune, P., Vermeulen, C. (2016): Cartographie de la dynamique de terroirs villageois à l'aide d'un drone dans les aires protégées de la République démocratique du Congo. - Bois Forets des Tropiques 315(1): 21-28.

[33] Nouri, J., Gharagozlou, A., Arjmandi, R., Faryadi, S., Adl, M. (2014): Predicting Urban Land Use Changes Using a CA-Markov Model. - Arabian Journal for Science and Engineering 39: 5565-5573.

[34] Ouedraogo, I., Tigabu, M., Savadogo, P., Compaoré, H., Odén, P. C., Ouadba, J. M. (2010): Land cover change and its relation with population dynamics in Burkina Faso, West Africa. - Land Degradation and Development 21(5): 453-462.

[35] Plourde, L., Congalton, R. G. (2003): Sampling method and sample placement: how do they affect the accuracy of remotely sensed maps? - Photogrammetric Engineering and Remote Sensing 69(3): 289-297.

[36] Pontius, G. R., Malanson, J. (2005): Comparison of the structure and accuracy of two land change models. - International Journal of Geographical Information Science 19(6): 243-265.

[37] Pontius, R. G., Millones, M. (2011): Death to Kappa: birth of quantity disagreement and allocation disagreement for accuracy assessment. - International Journal of Remote Sensing 32(15): 4407-4429.

[38] Potapov, P., Turubanova, S., Hansen, M., Adusei, B., Broich, M., Altstatt, A., Mane, L., Justice, C. 2012): Quantifying forest cover loss in Democratic Republic of the Congo 2000-2010, with Landsat ETM+ data. - Remote Sensing of Environment 122: 106-116.

[39] Ranagalage, M., Wang, R., Gunarathna, M. H. J. P., Dissanayake, D. M. S. L. B., Murayama, Y., Simwanda, M. (2019): Spatial forecasting of the landscape in rapidly urbanizing hill stations of South Asia: a case study of Nuwara Eliya, Sri Lanka (19962037). - Remote Sensing 11(15): 1743.

[40] Reid, R. S., Kruska, R., Muthui, N., Taye, A., Wotton, S., Wilson, C., Mulatu, W. (2000): Land-use and land-cover dynamics in response to changes in climatic, biological and socio-political forces: the case of southwestern Ethiopia. - Landscape Ecology 15(4): 339-355.

[41] Rendana, M., Rahim, S. A., Idris, W. M. R., Lihan, T., Rahman, Z. A. (2015): CAMarkov for predicting land use changes in tropical catchment area: a case study in Cameron Highland, Malaysia. - Journal of Applied Sciences 15(4): 689-695.

[42] Rogan, J., Chen, D. M. (2004): Remote sensing technology for mapping and monitoring land-cover and land-use change. - Progress in Planning 61(4): 301-325.

[43] Rosenfield, G. H., Fitzpatrick-Lins, K. (1986): A coefficient of agreement as a measure of thematic classification accuracy. - Photogrammetric Engineering \& Remote Sensing 52(2): 223-227.

[44] Roy, D. P., Lewis, P. E., Justice, C. O. (2002): Burned area mapping using multitemporal moderate spatial resolution data-a bi-directional reflectance model-based expectation approach. - Remote Sensing of Environment 83: 263-286.

[45] Salazar, A., Baldi, G., Hirota, M., Syktus, J., McAlpine, C. (2015): Land use and land cover change impacts on the regional climate of non-Amazonian South America: a review. - Global and Planetary Change 128: 103-119. 
[46] Salovaara, K. J., Thessler, S., Malik, R. N., Tuomisto, H. (2005): Classification of Amazonian primary rain forest vegetation using Landsat ETM+ satellite imagery. Remote Sensing of Environment 97(1): 39-51.

[47] Saputra, M. H., Lee, H. S. (2019): Prediction of land use and land cover changes for North Sumatra, Indonesia, using an artificial-neural-network-based cellular automaton. Sustainability (Switzerland) 11(11): 3024.

[48] Scholes, R. J., Van Breemen, N. (1997): The effects of global change on tropical ecosystems. - Geoderma 79(1-4): 9-24.

[49] Schönhart, M., Trautvetter, H., Parajka, J., Blaschke, A. P., Hepp, G., Kirchner, M., Zessner, M. (2018): Modelled impacts of policies and climate change on land use and water quality in Austria. - Land Use Policy 76: 500-514.

[50] Simwanda, M., Murayama, Y. (2018): Spatiotemporal patterns of urban land use change in the rapidly growing city of Lusaka, Zambia: implications for sustainable urban development. - Sustainable Cities and Society 39: 262-274.

[51] Singh, A. (1989): Review article: Digital change detection techniques using remotelysensed data. - International Journal of Remote Sensing 10(6): 989-1003.

[52] Sinha, P., Kimar, L. (2013): Markov land cover change modeling using pairs of timeseries satellite images. - Photogrammetric Engineering \& Remote Sensing 79: 10371051.

[53] Smits, P. C., Dellepiane, S. G., Schowengerdt, R. A. (1999): Quality assessment of image classification algorithms for land-cover mapping: a review and a proposal for a costbased approach. - International Journal of Remote Sensing 20(10): 1461-1486.

[54] Song, X. P., Hansen, M. C., Stehman, S. V., Potapov, P. V., Tyukavina, A., Vermote, E. F., Townshend, J. R. (2018): Global land change from 1982 to 2016. - Nature 560(7720): 639-643.

[55] Spera, S. A., Galford, G. L., Coe, M. T., Macedo, M. N., Mustard, J. F. (2016): Land-use change affects water recycling in Brazil's last agricultural frontier. - Global Change Biology 22(10): 3405-3413.

[56] Sterling, S. M., Ducharne, A., Polcher, J. (2013): The impact of global land-cover change on the terrestrial water cycle. - Nature Climate Change 3(4): 385-390.

[57] Tolba, M. K., Kenya, N., El-Kholy, O. A. (1992): The World Environment 1972-1992: Two Decades of Challenge. - https://doi.org/10.1017/CBO9780511840210.008.

[58] Townshend, J. R. (1992): Land cover. - Int. J. Remote Sens. 13(6-7): 1319-1328.

[59] UN-REDD (2012): Etude qualitative sur les causes de la déforestation et de la dégradation des forêts en République Démocratique du Congo. Un-Redd Program. - UNREDD, Geneva.

[60] Vadrevu, K. P. (2013): Introduction to Remote Sensing. Fifth Ed. - In: J. B., Campbell, Wynne, R. H. (eds.) The Photogrammetric Record. Guilford Press, New York. https://doi.org/10.1111/phor.12021.

[61] Velázquez, A. et al. (2003): Land use-cover change processes in highly biodiverse areas: the case of Oaxaca, Mexico. - Global Environmental Change 13(3): 175-184.

[62] Vieira, I. C. G., De Almeida, A. S., Davidson, E. A., Stone, T. A., Reis De Carvalho, C. J., Guerrero, J. B. (2003): Classifying successional forests using Landsat spectral properties and ecological characteristics in eastern Amazônia. - Remote Sensing of Environment 87(4): 470-481.

[63] Wanger, T. C., Iskandar, D. T., Motzke, I., Brook, B. W., Sodhi, N. S., Clough, Y., Tscharntke, T. (2010): Effects of land-use change on community composition of tropical amphibians and reptiles in Sulawesi, Indonesia. - Conservation Biology 24(3): 795-802.

[64] Weng, Q. (2002): Land use change analysis in the Zhujiang Delta of China using satellite remote sensing, GIS and stochastic modelling. - Journal of Environmental Management 64(3): 273-284. 
[65] Wondie, M., Schneider, W., Melesse, A. M., Teketay, D. (2011): Spatial and temporal land cover changes in the Simen Mountains National Park, a world heritage site in northwestern Ethiopia. - Remote Sens 3(4): 752-766.

[66] Wu, Q., Hong-qing, L., Ru-song, W., Juergen, P., Yang, H., Min, W., Bi-hui, W., Zhen, W. (2006): Monitoring and predicting land use change in Beijing using remote sensing and GIS. - Landscape and Urban Planning 78(4): 322-333.

[67] Ye, B., Bai, Z. (2008): Simulating land use/cover changes of Nenjiang County based on CA-Markov model. - IFIP International Federation for Information Processing 258: 321329.

[68] Zhuravleva, I., Turubanova, S., Potapov, P., Hansen, M., Tyukavina, A., Minnemeyer, S., Lapotre, N., Goetz, S., Verbelen, F., Thies, C. (2013): Satellite-based primary forest degradation assessment in the Democratic Republic of the Congo, 2000-2010. Environmental Research Letters 8: 024034. 